\title{
A Hot Mess: Girolamo Cardano, the Inquisition and the Soul
}

\section{Jonathan Regier (Ca' Foscari University of Venice) ${ }^{*}$}

\begin{abstract}
Girolamo Cardano makes a number of surprising, even shocking, claims about the soul in his De subtilitate, one of the most widely read works of natural philosophy in the sixteenth century. When he was finally investigated by the Roman Inquisition and the Index, these claims did not go unnoticed. This study will narrow in on three passages marked as heretical by the first Holy-Office censor of De subtilitate. It will consider the Inquisition's priorities and ask about materialism, determinism, and conceptual inconsistency in Cardano's views on the soul. The study will give special attention to the claim made by Cardano that souls can be reduced to celestial heat. In addition to De subtilitate, several other of Cardano's works will be considered for added perspective, especially Contradicentium medicorum libri duodecim.
\end{abstract}

Was there any position on life that could be construed as non-animist in the sixteenth century?

One is reminded of Lucien Febvre's famous denial of any atheist community in Renaissance Europe: the necessary social and intellectual conditions did not exist to support it (Febvre 1947). I would consider sixteenth-century "non-animism" far more intellectually untenable than atheism. Hylomorphism was so dominant that there was perhaps no conceptual language to describe an active, organized body without recourse to form - the soul, of course, was that form. Yet if soul was omnipresent, it also became a complex and contested entity in the period, this due to a number of factors: the diffusion of Platonic and Neoplatonic translations, the reintroduction of Epicurean and Stoic philosophies, an expanded Hippocratic and Galenic corpus, new readings of Aristotle, the accessibility of Greek and Arabic commentary, and confessional sensitivities. The soul, and specifically the rational or intellective soul, was a medical-philosophical-theological pressure point (e.g., Kessler 1988; Des Chene 2000;

\footnotetext{
${ }^{*}$ Acknowledgments: This paper owes its existence to a panel at the 2018 HOPOS congress in Groningen. I would like to thank all the participants of that panel, especially Charles Wolfe and Boris Demarest, who coorganized it with me. Much of this paper was written during a stay at Meiji University (Tokyo). I am grateful to my host, Kuni Sakamoto, and to Meiji University for that wonderful intellectual experience. Thanks are also due to the two anonymous referees and to HOPOS editor-in-chief Lydia Patton for all the hard work she has done to make this special issue a reality. Research presented here has received funding from the European Union's Horizon 2020 research and innovation program under the Marie Skłodowska-Curie grant agreement n. 893982.
} 
Michael 2000; Hirai 2011). In what follows, I would like briefly to consider Girolamo Cardano's (1501-1576) views of the soul and how they were read by censors of the Roman Inquisition. Censorial reports have an inherent interest, since they show us where the institutional guardians of doctrine put their proverbial foot down. Beyond that, they can act as an interpretative filter through which to consider Cardano's works. These readers, although biased, are still much closer to Cardano in time, space and culture than we are. In fact, thanks to their biases, the censors located a real tension in his work: he does generally maintain a level of discourse privileging the soul's immateriality and immortality; yet, as a natural philosopher and medical writer, he can be read as veering into a kind of materialism and physical determinism.

Most studies of Cardano's writings on the soul have concentrated on his De immortalitate animorum (e.g., Maclean 2003 \& 2008; Cardano 2006; Giglioni 2007; Canziani 2012; García Valverde 2013). However, this treatise received little attention from Inquisition censors, a fact likely due to historical contingency rather than to a selective program on their part. Initially, the trial began over accusations stemming from passages in De rerum varietate (1557), a comprehensive treatise of natural philosophy and sequel to Cardano's most widely read book, De subtilitate (1550). As censorial attention expanded, it encompassed both De subtilitate and works of moral philosophy and astrology (Regier 2019). De subtilitate's doctrine of the soul came under heavy attack from that work's first censor, a noteworthy figure in Inquisition history. In what follows, I will examine De subtilitate by considering three passages on the soul isolated by this censor and given the stamp of "heresy." In doing so, I will draw some conclusions both about the Inquisition's intellectual priorities and about what looks like an inconsistency at the heart of Cardano's theory of the soul: when his corpus is taken in as a whole, he cannot seem to decide whether the individual soul, human or otherwise, should be identified with heat, or whether heat was only the soul's first instrument. Alfonso Ingegno 
suggested that there was perhaps no solution to this question, that Cardano may have believed a definite answer unnecessary to "a concrete knowledge of nature" (Ingegno 1980, 234). Other scholars have put Cardano on one or the other side of the issue, either for or against the soul as heat (Schütz 2000, 119-125; Sakamoto 2016, 37-42; Giglioni 2019). It may be tempting to conclude that Cardano was not only ambiguous on this question but inconsistent. My reading of Cardano will offer something of a resolution. As the self-proclaimed philosopher of variety and subtlety, Cardano embraced ambiguity to an extent that jarred even his near contemporary readers, yet he was not, on this point of the soul, inconsistent. One of his lifelong projects was to prove that natural philosophy could confirm the immateriality and immortality of the soul, this against the threat posed by Pietro Pomponazzi. Yet the natural philosophy that he constructed to do so had the opposite effect on Inquisition readers, who saw materialism and determinism. In explaining the immortal human soul within a natural framework-within a web of physical causation-, Cardano made it ever more evident how the soul might be reduced to such a natural framework. There is an irony here that can perhaps be found in the reception of much non-Scholastic philosophy of the sixteenth and seventeenth century: where it tried to bolster Christian doctrine, it opened itself to accusations of undermining said doctrine. ${ }^{1}$ Scholasticism was not merely a traditional structure of reason and revelation; it was a hardwon, negotiated geography between many parties with many interests-philosophical, theological and otherwise. The tensions in Cardano's work and its reception offer a revealing case study of how those borders were fought over and reshaped in the intellectual conflicts of the sixteenth century.

\footnotetext{
${ }^{1}$ This assertion might be usefully compared with Alan Charles Kors's thesis on the emergence of atheism in early-modern France: "Early-modern theists, Catholic, Protestant, and heterodox [...] were the source or conduit of such [atheistic] argument and the discovers or creators of such atheistic teaching” (Kors 1990, p. 79).
} 


\section{Laughing Babies and Immortal Souls in the Contradicentia medica}

"Since truth cannot at all contradict truth, we define as utterly false any assertion contrary to the clear truth of faith." ${ }^{2}$ Hence, the Catholic Church declared in 1513 that philosophy could offer no separate truth from theology. There would be no "double truth," one for the secular mind and another for the faithful heart. The target of this papal bull, Apostolici regiminis, was teachings on the mortality of the rational soul associated with Pomponazzi and Paduan Averroists. These teachings, said the bull, went against the word of the bible and robbed Christians of the resurrection and eternal life secured through Christ. Wherever the interests of philosophy overlapped with those of faith, the former had to accommodate the latter. The philosophy of Girolamo Cardano, a diverse and hugely complex body of work, is selfconsciously faithful to this one-truth doctrine. Cardano famously battled the undying ghost of Pomponazzi; philosophy could, said Cardano, establish that the human soul never dies. What is more, philosophy could demonstrate that the individual human, body and soul, were subject to a natural resurrection (Maclean 2003; Giglioni 2007; Canziani 2012). That is, Aristotelian philosophy_correctly understood—suggested a resurrection or prefigured the Catholic doctrine imperfectly, the way a sketch prefigures a painting (Cardano 1663, II.529b).

Before turning to De subtilitate, we might first examine the celestial heat doctrine as it appears in Book VI of Contradicentium medicorum libri duodecim, a work published in its most complete form posthumously but begun decades earlier in the 1520 s and significantly reworked over Cardano's life. ${ }^{3}$ There, we can read how Cardano believes himself to draw the doctrine from Hippocrates, how the doctrine meshes with his psychological views and his

\footnotetext{
2 "Cumque verum vero minime contradicat, omnem assertionem veritati illuminatae fidei contrariam, omnino falsam esse definimus [...]" The text of the 1513 Bull Apostolici regiminis can be found in Constant 2002, $377-$ 379. For the double-truth issue, see Bianchi 2008.

${ }^{3}$ Book I of Contradicentium medicorum was published in 1545, Books I and II in 1548. The remainder of the books were published posthumously in the 1663 Opera omnia. See Cardano 2004, 51-52.
} 
reading of Galen, and how it leaves the soul's ultimate nature ambiguous, all in a chapter devoted to the question of "whether, according to medical opinion, the human soul is immortal" (Cardano 1663, VI.764a-767b). It is no surprise that Cardano begins the chapter with Hippocrates, who, he says, believed the soul to be immortal. Hippocrates was not only a source for Cardano, but he was a model and hero (Siraisi 1997; Hirai 2011, 110-114). Cardano quotes from the beginning of the Hippocratic text De carnibus, a work unique for its explicit cosmogony. De carnibus links the elemental formation of the world with the emergence of animal parts. So, for example, we learn that the earth was originally dry. After a long time, a kind of putrefaction began to appear; and after another long period, the fatty and less humid parts of this putrefied substance began to burn, thus forming bones. But not everything burned, since there were stickier masses; these sticky masses formed solid nerves (nervi solidi). Veins began as cold masses; heat burned their outsides, forming an envelope that became a membrane; meanwhile, the cold interior of the veins melted and became liquid. None of this seems particularly amenable to Genesis; instead, the human emerges as an outcome of a prolonged elemental process. Cardano reproduces the very beginning of the chapter, on the earliest stage of cosmic existence. Here, the emphasis is on a divine, pneumatic heat - a first principle of order and generation.

And it seems clear to me [the author of De carnibus] that what we call heat is immortal, that it understands, sees, and knows everything together, as much the present as the future. So, the better share of it, when everything was in a state of confusion, withdrew itself to the celestial circumference. And it seems to me that the ancients called it Aether. $^{4}$

\footnotetext{
4 "Et videtur sane mihi id quod calidum vocamus, immortale esse, \& cuncta intelligere, \& videre, \& audire, \& scire omnia, tum praesentia, tum futura. Huius igitur plurima pars, quum turbata essent omnia, in supernam circumferentiam secessit. Et videntur mihi ipsum veteres Aethera nominasse" (Cardano 1663, VI.764a). Hiro Hirai also translates this passage in Hirai 2011, 112-113. Also see Hirai 2019.
} 
This heat is distributed in various degrees throughout the elements, infusing the elements and serving as a primary source of life and generation. Cardano held Hippocrates to identify the soul with celestial heat, which was indestructible: "Since [Hippocrates] judged that man was constituted of these four [elements], and that the soul is that heat, he wanted, without any doubt, the soul to be immortal." 5

What follows, then, is a long passage taken from the Hippocratic De diaeta, whose sense, says Cardano, is that Hippocrates did not believe in material corruption, but only in separation and dissipation. The absence of corruption is also a cherished tenet of Cardano's physics: corruption for one substance is merely generation for another. Mutability is the constant; corruption and generation are relative. "It is clear that the soul, according to Hippocrates, is immortal, not capable of being corrupted." ${ }^{\circ}$ But Cardano allows that Hippocrates may not (presumably on physical grounds) have forbid the possibility of the soul's dissipation. Yet, he hastens to add, the immortality of the soul-its non-dissipation-is established by Hippocrates in "a most beautiful argument" from Liber de septrimestri partu [On the Seven Month Infant], a rather idiosyncratic Hippocratic text. ${ }^{7}$ Cardano cites a startling passage where its author suggests that in new-borns, "a certain particular knowledge is manifest in the body from the first day." Why? Because new-borns laugh in their sleep, says the author; but awake, they cannot laugh until their fortieth day. The exact nature of this innate knowledge is unexplained in the Hippocratic text. But for Cardano, Hippocrates is clearly writing about the knowledge of the baby's immortal soul, whose substance is the celestial heat from $D e$ carnibus: "Therefore, before knowledge by external senses, there is knowledge via interior [faculties]; therefore, the soul exists naturally before it is poured into the body, and it is a

\footnotetext{
5 "Cum ergo censeat hominem ex his quatuor constare $\&$ animam esse calidum illud, haud dubiè animam immortalem esse voluit” (Cardano 1663, VI.764a).

6 "[...] liquet animam iuxta Hippocratem esse immortalem, nec posse corrumpi [...]" (Cardano 1663, VI.764b).

${ }^{7}$ As one recent scholar has noted, this text lacks clear structure and "does not have much in common with mainstream Hippocratic gynaecology" (Craik 2015, 246-249).
} 
substance that knows everything, and it is that sempiternal and immortal heat which knows all." $" 8$

In early-modern medical frameworks-Hippocratic, Galenic and Aristotelian-, innate heat and medical spirits (the latter were generally thought to carry heat [Moreau 2015]) were considered instruments of the soul, rather than the soul itself. Their circulation undergirded an endless variety of bodily phenomena. Sixteenth century medicine featured quite materialist views on the soul's functions or operations, including the psychological; Aristotle's De anima came to be grounded in anatomy, as Katharine Park has richly described (Park 1988). Such materialism could be a worry from a doctrinal point of view, and most writers were clear to differentiate the soul from its material instruments. One might expect Cardano, then, to make some distinction between soul and heat. But he does not. What he does do, after his introduction to Hippocratic heat, is establish the immateriality of the intellective soul. Immateriality is the sine qua non of immortality; immaterial things are incorruptible, therefore they cannot die. As for why the intellective soul cannot be material or mortal, Cardano offers a typical grab-bag assortment of arguments: for example, that the telos of the mind is to meditate upon God, its maker; that the mind can have knowledge without the body; that a man no longer grows in physical strength after forty, while this age marks only the beginning of his increasing intellectual strength (a bad-news-good-news situation); that the mind has an infinite virtus, demonstrated by its ability to know mathematical infinity; that only an immaterial mind can know universals (Cardano 1663, VI.764b-765b). These arguments are very much in keeping with the tenor of his De immortalitate animorum.

The question is whether, here in the Contradictiones, Cardano endorses Hippocrates on the soul as celestial heat. It is extremely common for a writer of the period to compare and

\footnotetext{
8 “"...] igitur ante cognitionem per sensus exteriores, cognoscit per interiores; ergo anima natura est antequam in corpus infundatur, \& est substantia quae cognoscit omnia, \& est calidum illud sempiternum \& immortale omnia sapiens" (Cardano 1663, VI.764b).
} 
qualify ancient sources. And that is what Cardano does: beginning with Hippocrates, moving to Aristotle, then to Galen. After commenting on Hippocrates, he goes right into a demonstration of the soul's immateriality and immortality on theological and psychological grounds. It may therefore seem that Cardano criticizes Hippocrates for a too-materialist stance. This is probably not the case. Cardano actually wrote a commentary on the Liber de septrimestri partu, published in 1568 , and while celestial heat is mentioned only briefly, he suggests that it be understood as immaterial and intellective, as the "incorporeal force instilled in our minds by the creator" (Cardano 1663, ix.31b). ${ }^{9}$ Hence, in the Contradictiones, Cardano also likely read Hippocratic heat as immaterial, a prefiguration of the Christian soul. As usual, Hippocrates should be taken as an ally and source of prisca sapientia. But there remains room for confusion. In Cardano's De immortalitate animorum, heat and spirt are merely instruments of the soul. In his Theonoston seu de tranquilitate (posth. $1617 \& 1663$ ), he addresses outright whether the soul can be an innate heat from the heavens (calor innatus conflatus ex coelesti). It cannot. There are three principles in us: something that is moved and does not move - the elemental body; something that moves but is not moved - the soul; something that is moved by the soul and moves the body — heat (Cardano 1663, II.304b; Giglioni, 2019).

Cardano has, by our standards, a quixotic reading of Hippocrates. If we take the Contradictiones, clarified by Theonoston, then his celestial heat looks quite a lot like the spiritus mundi of Marsilio Ficino's De vita libri tres (1489), an entity which serves as the instrument of the anima mundi. ${ }^{10}$ Other passages from Cardano's corpus support this conclusion. In his De arcanis aeternitatis (posth. 1663), he lists the anima mundi as just below God in a quasi-emanationist ontological hierarchy. Cardano's world soul unloosens or unfolds the unity of God into individual beings, much like Ficino's world soul institutes divine ideas

\footnotetext{
${ }^{9}$ In librum Hippocratis de septimestri partu commentaria (1568).

${ }^{10}$ Hiro Hirai has pointed out that Cardano's celestial heat can be read to operate as an instrument of the anima mundi (2005, 141-143).
} 
in matter. And like Ficino, Cardano makes the world soul the first principle behind all other motion in the cosmos: it elaborates the infinity of God into an unending succession of finite moments. It seems likely that Cardano saw celestial heat as the instrument of this anima mundi. That is, just as heat and spirit serve as intermediaries between an incorporeal animal soul and its body, the cosmos itself needs an intermediary between its soul and its elements. Like Ficino's spiritus mundi, Cardano's heat is at once a cosmic and a medical or anatomical entity, connecting individual bodies to the wider world. (Cardano 1663, X.6b; Ficino 1989, 244-249).

Cardano's world soul and celestial heat also play a role in God's plan for the world. Like so many medieval and Renaissance astrologers (North 1980), Cardano thought that God had tuned the heavens in order to bring about historical transformations. Cardano actually gives this idea an original twist. A spark for his Inquisition trial-and an accusation that would remain central in censor reports - was that he made celestial heat responsible for religious fragmentation. In De rerum varietate, he writes of how celestial heat drives priests and heretics to invent new forms of worship and to sacrifice themselves for the sake of absurd theological fabrications (Cardano 1663, III.31b-33a; Regier 2019). Cardano's anima coeli also serves as an instrument of God to punish humanity for its greatest sins, as Cardano explains in an extraordinary passage brought to scholarly attention by Jean Céard. That is, Cardano naturalizes divine castigation: grave human sins disrupt nature to such an extent that celestial influence, God's instrument for preserving the world, cannot correctly act on sublunar matter, leading to monstrous beings, general chaos and turpitude (Cardano 1663, III.272b-273a; Céard 1977, 248-249).

\section{Celestial Heat and the Pneumatics of Desire in De Subtilitate}

In 1570, the Inquisition brought Cardano to trial in Bologna, where he was a professor of medicine. This trial, settled in 1571, led to a prohibition by the Index of all his non-medical 
books in 1572 (Valente 2003 and 2017; Regier 2019). The Holy Office and Index would continue to amass censor reports (censurae) on his works over the next three decades. Cardano's Inquisition documents are now accessible, having been edited and published by Ugo Baldini and Leen Spruit (Baldini and Spruit 2009, t.II 1033-1472). I would like to consider the first report on De subtilitate, written for the Holy Office in the summer of 1572 by Alfonso Chacón, a notable humanist who later occupied a prominent position in the Congregation for the Index (Baldini and Spruit, 1135-1172). Chacón was, by Inquisition standards, a sympathetic reader. His censura on De subtilitate is structured according to the severity of the propositions in question: it begins with the unquestionably heretical, then passes on to progressively lower grades of severity. As mentioned above, Chacón finds only three passages in the entire $D e$ subtilitate to be heretical. All of them concern the soul. In what follows, I would like to consider these passages along with Chacón's commentary.

De subtilitate was first published in 1550 , with a revised edition in 1554 . This was the period when Cardano started writing Theonoston (Cardano 2004, 95-97). There is a marked difference, however, on the question of celestial heat. In the 1554 and later editions of $D e$ subtilitate (Schütze 2000, 120), Cardano comes right out and claims the soul to be celestial or natural heat, this at two moments that would be flagged by the Inquisition. The first is in Book II, on the elements, where we read that heat always generates something, even if it destroys another thing at the same time. In this process of generation within putrefaction, says Cardano, "the actual substance of the soul is evident, because it consists in some celestial heat." Alongside this passage, in the margin of the 1560 edition (the edition read by the censor whom we will visit below), is a printed note reading "Anima quid sit" (Cardano 1560, 147). Cardano continues by writing that celestial heat is not an instrument of the soul, nor the soul's cause, "but it is the soul." With this, Cardano cites Anaxagoras and affirms that "all things are mingled, and endowed with soul," which is perhaps an echo of Ficino, who writes in the De 
vita that, "there is nothing to be found in this whole living world so deformed that Soul does not attend it, that a gift of the Soul is not in it" (Cardano 1663, 388; Cardano 2013, 122; Ficino 1989, 245). Cardano claims that celestial heat should not be confused with the original form of the body. It is, rather, another kind of form, a vivifying form. Here, he again reveals an extremely important feature of celestial heat: it is immaterial; it is only described as "corporeal" because it cannot exist without a body. Hence, the body has its own form, perishable, and the soul qua celestial heat must be distinguished as a separate kind of imperishable form. This leads him to make the claim that "every soul is permanent in the same way [eodem modo perennis], and not as Plato says, only the souls of the perfect animals" (Cardano 1663, III.389; Cardano 2013, 124). The censor seizes on this point, which denies the distinction between the souls of brutes and the rational souls of humans. This, believes the censor, is tantamount to denying the rational soul its special status (Baldini and Spruit 2009, 1136).

Cardano's statement on the immortality of all souls was motivated by an appeal to their common substance, celestial heat. The censor confronts the Hippocratic doctrine directly, this in a passage from Book V, on mixtures. Cardano argues that common to all living things is the celestial heat which mixes their elements (the more perfect an animal, the better mixed and the hotter). At one point, Cardano does mention, in a single clause, that humans are the exception to this rule (Cardano 1663, 434b; Cardano 2013, 276). In any case, Cardano again writes that Hippocrates was correct to describe soul as nothing except celestial heat. But a moment later he adds, "For whether heat is the soul, or the soul's primary instrument, where heat appears the soul evidently ought to be present as well, hence life too-indeed, life is nothing but what the soul does" (Cardano 1663, III.440; Cardano 2013, 293). The censor ignores the above qualification. He first quotes the passage, accurately, before offering his assessment:

According to the faith, the human soul is an immortal substance created by God. Thus, it is heretical to say that [the soul] is nothing but celestial heat. Because if it were 
celestial heat, it would be called an accident, not a substance, because it cannot be immortal without a subject. ${ }^{11}$

Here, Chacón seems to be suggesting that heat is an accidental quality, that an identification of the soul with heat would mean the soul too could only be accidental rather than substantial. Curiously, he overlooks or brushes aside the many arguments Cardano has made about the substantial and formal nature of heat. This fact may say as much about how he read qua censor as it does about his theological and philosophical entrenchment.

The third passage flagged as heretical concerns, in finer grain, the relationship between the human soul and the body, this in a wider treatment of sexual love and desire. Before we get to the passage itself, some discussion would be useful on Cardano's view of human nature, which, as he elucidates it in De subtilitate, reduces more or less to bodily flesh, fluid and vapor. In distinctly Renaissance terms, Cardano affirms the incredible plasticity of the human, which embraces the universal bulk of all things (universam rerum omnium molem videtur amplecti). Then he goes his own way, chalking up our universality to the power of the menstrual blood from which we are assembled (coagmentatur). What is it about menstrual blood that makes it so powerful? Heat, of course, a heat so intense that it can purge leprosy, a cure that Cardano claims to have witnessed. Cardano invokes the Sun in reference to the generative female body: just as the Sun's heat can overwhelm and extinguish lesser fires, menstrual blood is a powerful stimulant and purgative (Cardano 1663, III.557; Cardano 2013, 667-668). ${ }^{12}$ At the most fundamental level, says Cardano, heat and moisture are the primary ingredients of life, a Hippocratic doctrine traced to De carnibus. Humans are especially hot and moist, hence our long life. But this abundance of heat and moisture also makes us sinful. Our wickedness comes

\footnotetext{
11 "De fide est animam humanam substantiam esse immortalem a deo creatam; qua re haeresis est dicere, nihil aliud esse quam caeleste calidum. cum caeleste calidum, accidens sonet non substantiam quod immortale citra subiectum esse non po<tes $>$ t." (Baldini and Spruit 2009, 1137)

${ }^{12}$ Cardano suggests a clear connection between the Sun and womb (Cardano 1663, III.557; Cardano 2013, 666). In Renaissance literature of all stripes, the Sun is usually linked to the masculine, the Earth to the feminine.
} 
from heat, our indolence from moistness. "This is why wise men," writes Cardano, "being of a very hot nature and very moist, are the worst of all unless they make progress in philosophy. In that, they are helped by the industry they have acquired from their studies, and by melancholy, which is generated by the dissipation of fattier humour from excessive studies and lack of sleep" (Cardano 1663, III.558; Cardano 2013, 670).

Unsurprisingly, sexual love and desire are also affairs of heat and moisture. Humans, says Cardano, are of all the land animals the most apt or prepared (paratus Veneri) for sexual love. ${ }^{13}$ But wise men can suffer from a lack of desire, because their spirits are concentrated in their brains, not below their belts; they are hot of head and cool of loin. Now, we might consider this a virtue: Cardano looks to be giving a physiologically-grounded account of something like sublimation, with the wise liberated from the need to consummate their sexual desires. But Cardano is always quite practical about the body and its passions. This pneumatic chastity of the learned ends up being an inconvenience; occasional sex remains the most effective way to relieve stress. And then there is a problem of greater weight: intellectuals sire feeble children, since their spirits are not properly focused for procreation. What follows is advice for maintaining a healthy level of appetite, as well as practical tips for tackling erectile disfunction that wise men suffer, owing to their misplaced spirits. The whole point, though, is that the flow of bodily spirits drives the process of sexual desire. Since spirits are involved in higher level functions, passions and personal predilections strongly affect sexual activity. Cardano claims to have witnessed men get erections while they were being executed by hanging. He mentions en passant that some men cannot get erections unless they are giving or taking a beating (Cardano 1663, III.558; Cardano 2013, 671-672).

\footnotetext{
${ }^{13}$ Birds, he thinks, are even friskier, and in the De secretis he claims that the dove is the hottest of all animals (Cardano 1663, II.546a). Cardano's thoughts on the psychology and physiology of love could, I believe, benefit from a comparison with Ficino's philosophy of spiritual love, especially as it was interpreted by Ioan Petru Culianu (Culianu 1984).
} 
As fun as it is to read about Renaissance sadomasochism, these musings on human sexuality are important when we consider the status of the soul. In Book XIII, on the senses and pleasure, Cardano discusses in more detail the nature of human sexual desire. Here, the sensory image of the beloved, brought into the mind via sight, proves a forceful agent as it interacts with internal mathematical ideals of beauty (basically Vitruvian proportions). Very rarely can the external match these internal expectations. "Men who can see sharply love less," says Cardano, "and not only less, but less often [...]." Love, it turns out, is not blind but only short-sighted. Cardano continues:

So most men are in love because their vision is impaired, or they are in love before looking at what they fancy loving. This is why very many men are in love even against their will; they are forced into it in the presence of an image of beauty just like those who are seared by grief, and the power of imagination does not entirely comply with the will; and if you do imagine something beautiful, you are not free to withhold your love. So when a beautiful form is accepted into the power of imagination, we are snatched away into love even against our will. This is why scholarly people are more powerfully in love, because of the strength of their imagining faculty. (Cardano 1663, III.572; Cardano 2013, 706-707)

Cardano has a pragmatic, even cynical, position on our amorous responses to beauty. Our imagination fuses the sense object with internal ideals of beauty, creating a romanticized figure of great power. All of this is essentially physiological; the will does not, perhaps cannot, intervene. For the male lover, what happens next is an involuntary pneumatic response, a flow of spirit, heat and moisture:

Erection in fact takes place from imagining-for instance, when an attractive image is presented from the brain to the soul, the heart (where the soul dwells) transmits spirit and heat to the penis, exciting titillation in it through nerves from the brain. So, while 
heat is making its way into it, it disperses the moistness on the route and turns it to flatus; with the insertion of this into the pumice-like flesh of the penis, erection at once occurs. This makes clear that the primary and entire soul is in the heart. (Cardano 1663, III.572; Cardano 2013, 707)

It is amusing to imagine an Inquisition censor reading the above, a kind of physiological flowchart connecting brain, heart and genitals, the soul a thermic motor powering the whole process. There is a mechanism here, or, better yet - in order to avoid the inevitable comparison with later mechanisms - there is a kind of pneumatic reductionism: a reduction of the human to the circulation of heat. In turn, love, desire and arousal are immediate manifestations of the soul, that is, of heat circulating with purpose through the body.

The censor's objections are, in fact, to the passage denying a lover's capacity to withhold love:

[Cardano] says [the following], speaking of the imaginative virtue. For this reason, many, even if they do not want to, love and are moved to love by an image of beauty presenting itself $[\ldots]$

This opinion is heretical. Necessity of the will is asserted on account of the beautiful object. The will is never carried necessarily to any object except God clearly seen and the blessedness common to everything. [The will] is free in regard to other objects, given that it can follow or reject an object, however beautiful. Otherwise, man would not be the master of his acts, nor would he sin on account of the beloved, since the beautiful thing would have simply been cast before his sight. That is heretical, for if he is impelled by necessity, the will could not have done otherwise, and so the sinning 
on account of the beautiful object would not be imputed to the man, and it would be impossible for the man to abstain from $\sin .{ }^{14}$

In the above, we find the absolutely fundamental point in the Inquisitorial case against Cardano. Again and again, censors relented against his naturalization of the human when they felt that it infringed on man's choice to sin or not. The recent Council of Trent had re-established human freedom to accept or deny spiritual gifts, this over and against Reformation doctrines questioning humanity's spiritual agency. Cardano's astrology and celestial physics were attacked on precisely these grounds. They suggested to Inquisition censors that celestial forces constrain us to follow either a godly or a wicked path; they suggested that the heavens, rather than God's punishment and approbation, ruled the rise and fall of religions and civilizations (Regier 2019). The Inquisition's reading of Cardano was first and foremost doctrinal; censors preferred not to engage with Cardano on his own terrain, that is, by refuting him philosophically or medically (although there were exceptions). Alfonso Chacón opposed Cardano's view of the soul where it threatened to undermine human freedom to sin and God's, or the Church's, authority to render justice. The same goes for the soul's immortality. Although Chacón does not outright say so, when we look at the Roman Catechism, otherwise known as the Catechism of the Council of Trent, we find that the soul's immortality was not defended for itself but as a necessary component of divine justice (Catholic Church 1829, Article XI: 115-126). And divine justice, from a rigorous Catholic perspective, depended on the freedom to choose good or evil. To summarize, Chacón's censorial attention reveals an underlying preoccupation of Catholic orthodoxy: the soul of De subtilitate - a natural philosophical entity woven into the

\footnotetext{
14 "De virtute imaginatrice loquens, ait. Ea de causa plurimi etiam si nolint, amant, coguntur enim amare presente pulchritudinis imagine [...]

Haec sententia est haeretica, qua astruitur necessitas voluntatis $\mathrm{pr}<$ aese $>$ nte obiecto pulchro. Nunquam enim voluntas fertur necessario in aliquod obiectum praeter deum clare visum et beatitudinem in communi: ad caetera obiecta libera est, ut possit persequi aut refutare obiectum quantumvis pulchrum. Alias homo non esset dominus suorum actuum neque peccaret amando quod pulchrum visui obijceretur: quod est haereticum; nam si necessario fertur, non potuit voluntas aliter facere, et sic peccare $\mathrm{pr}<$ aese $>$ nte obiecto pulchro non esset homini imputandum, et impossibile foret homini à pe<cca $>$ tis abstinere" (Baldini \& Spruit, p. 1137).
} 
fabric of celestial and terrestrial causes - could easily be stripped not only of its ontological uniqueness, but also of its capacity to transcend natural causes and so exercise free will. Clearly, in his medical and natural philosophical mode, Cardano is far more interested in causes that determine human bodies and behaviours than in liberty from said causes, which is to say, free will. In De subtilitate, he strives to explain the greatest diversity of physical phenomena from fundamental causes. This is the key to making sense of nature's endless variety and subtlety. Of all the fundamental causes, none is so omnipresent, of such diverse manifestations, as celestial heat.

While this is not the place to do so, at least not with any kind of comprehensiveness, I would argue that De subtilitate can be read as a treatise primarily devoted to the many effects of heat as it circulates through the cosmos, creating life and change. But Cardano's "pananimism" raises many questions that go unanswered. How are souls differentiated? One possibility given by Cardano is that different kinds of souls are characterized by different kinds of heats, hence the heat of scorpions causes decay and corruption in humans (Cardano 1663, III.389; Cardano 2013, 124). Likewise, the heat of Saturn is beneficial to some beings, while not to humans (Cardano 1663, V.120b-121a). This is reminiscent of Averroes, who in his Long Commentary on the Metaphysica has the planets contributing different heats to the sublunar world, with each kind of heat responsible for the generation of distinct animal species (Freudenthal 2009, 270). The Averroes-Cardano connection must remain speculative for the moment. Another question pertains to the nature of an immaterial celestial heat. In certain works, Cardano expresses clearly that the soul is immaterial, that heat is its first instrument. Elsewhere, in works of more or less the same period, he agrees with his Hippocrates that soul is nothing but an immaterial celestial heat. ${ }^{15}$ The source of this inconsistency centres on the

\footnotetext{
15 This does not preclude an evolution in Cardano's thought. It only makes a clearly traceable evolution unlikely.
} 
behaviour of immaterial things. When Cardano separates soul and celestial heat, it is because the former must be motionless, while the latter is mobile. When he identifies them, he renders heat immaterial, all while implying that it circulates. What kind of ontology could this imply, this combination of circulation and immateriality? In the early-modern period, light could be thought of as incorporeal but physically active and fully comparable with medical spirits. A highly articulate example of this view can be found in Johannes Kepler's optical works (Regier, 2014). In De subtiliate, Cardano likewise speaks of light and heat as one rather than separate (Cardano 1663, III.418; Cardano 2013, 223). Light, in a sense, allows for a kind of motion that is also non-motion, since it is instantaneous. Thus, when Cardano writes of celestial heat as both immaterial and capable of motion, he might very well be thinking of light and even of light as intellect, an analogy stamped brightly in his De immortalitate animorum - and an analogy that approached identity. Finally, we might add one final note. We saw that Cardano makes the distinction between an immobile soul and mobile heat very clear in Theonoston seu de tranquilitate, a treatise on the virtue of tranquillity. As Guido Giglioni has established, this highest human virtue does not equal perfect stillness for Cardano; rather, it is a calm vigour, social and intellectual (Giglioni 2006 \& 2019). The human, both ethically and physiologically, is always moving.

\section{Conclusion}

Cardano's ambiguities are revealing of wide transformations in the sixteenth century, when natural philosophy and medicine became ever more comfortable examining the soul within their respective frameworks. As we find in Cardano, this physicalization of the soul was not meant as a gesture of antagonism toward Christian doctrine or confessional authorities. It was meant as reconciliation. Nevertheless, the result was that soul took on, more and more fully, physical and material properties, such that it risked becoming indistinguishable from its 
first physical manifestations, heat or spiritus, which were tailor-made to function as common causes behind diverse phenomena. Cardano, it seems, could just as well account for the intellective soul with an immaterial celestial heat. Perhaps this possibility, an idea of striking heterodoxy, lies at the heart of his perceived ambivalence.

One final point should be made about the Inquisition's sensitivity to threats that philosophy posed to free will, a sensitivity clearly at play in the censor's response to the bodily determinism that he read in the third passage above. As mentioned, the Inquisition was essentially an organization for doctrinal purity and usually avoided any but the most necessary philosophical engagements. Yet their attitude implied at least two tacit philosophical positions: the first was that philosophy should strive toward doctrinal agreement; the second was that, if free will could not be understood through natural inquiry, or if natural inquiry denied it, then the intellective soul had to be a singularity in the natural landscape, a black box whose interior would remain impervious to the methods of philosophers.

\section{References}

Baldini, Ugo and Leen Spruit. 2009. Catholic Church and Modern Science: Documents from the Archives of the Roman Congregations of the Holy Office and the Index, Vol. 1: SixteenthCentury Documents. Rome: Libreria Editrice Vaticana.

Bianchi, Luca. 2008. Pour une histoire de la “double verité.” Paris: Vrin.

Canziani, Guido. 2012. "L’immortalité de l'âme chez Cardan, entre histoire naturelle et vision de Dieu." In La pensée scientifique de Cardan, ed. Jean-Yves Boriaud, 161-184. Paris: Les Belles Lettres.

Cardano, Girolamo. 2013. The "De Subtilitate” of Girolamo Cardano, 2 vols. Trans. John M. Forrester. Tempe: Arizona Center for Medieval and Renaissance Studies.

---. 2006. De immortalitate animorum. Ed. José Manuel García Valverde. Milan: Angeli. 
---. 2004. De libris propriis: The Editions of 1544, 1550, 1557, 1562, with Supplementary Materials. Ed. Ian Maclean. Milano: Angeli.

---. 1663. Opera omnia, 10 vols. Ed. Charles Spon. Lyon: Jean-Antoine Huguetan and MarcAntoine Ravaud.

---. 1560. De subtilitate libri XXI. Basil: Heinrich Petri.

Catholic Church. 1829. The Catechism of the Council of Trent, Published by Command of Pope Pius the Fifth. Trans. Rev. J. Donovan. Dublin: W. Folds and Son.

Céard, Jean. 1977. La nature et les prodiges. L'insolite au XVIe siècle, en France. Geneva: Droz.

Constant, Eric A. 2002. “A Reinterpretation of the Fifth Lateran Council Decree Apostolici regiminis (1513).” The Sixteenth Century Journal 33:353-379.

Craik, Elizabeth M. 2015. The 'Hippocratic' Corpus: Content and Context. New York: Routledge.

Culianu, Ioan Petru. 1984. Éros et magie à la Renaissance. 1484. Paris: Flammarion.

Des Chene, Denis. 2000. Life's Form: Late Aristotelian Conceptions of the Soul. Ithaca: Cornell University Press.

Febvre, Lucien. 1947. Le problème de l'incroyance au XVIe siècle. La religion de Rabelais. Paris: Éditions Albin Michel.

Ficino, Marsilio. 1989. Three Books on Life. Trans. and ed. Carol V. Kaske and John R. Clark. Tempe: Arizona Center for Medieval and Renaissance Studies.

Freudenthal, Gad. 2009. "The Astrologization of the Aristotelian Cosmos: Celestial Influences on the Sublunar World in Aristotle, Alexander of Aphrodisias, and Averroes." In 
New Perspectives on Aristotle's De caelo, ed. Alan C. Bowen and Christian Wildberg, 239281. Leiden: Brill.

García Valverde, José Manuel. 2013. “Averroistic Themes in Girolamo Cardano's De Immortalitate Animorum." In Renaissance Averroism and Its Aftermath: Arabic Philosophy in Early Modern Europe, ed. Anna Akasoy and Guido Giglioni, 145-171. Dordrecht: Springer.

Giglioni, Guido. 2005-2007. "Mens in Girolamo Cardano." In Per una storia del concetto di mente, ed. Eugenio Canone, vol. 2, 83-122. Florence: Olschki.

---. 2006. "Girolamo Cardano on the Passions and their Treatment." Bruniana \& Campanelliana 12:25-40.

---. 2007. "The Eternal Return of the Same Intellects: A New Edition of Girolamo Cardano's De immortalitate animorum." Bruniana \& Campanelliana 13:177-183.

---. 2019. "Girolamo [Geronimo] Cardano." In The Stanford Encyclopedia of Philosophy, ed. Edward N. Zalta. https://plato.stanford.edu/archives/sum2019/entries/cardano/.

Hirai, Hiro. 2005. Le concept de semence dans les théories de la matière à la Renaissance: de Marsile Ficin à Pierre Gassendi. Turnhout: Brepols.

---. 2011. Medical Humanism and Natural Philosophy: Renaissance Debates on Matter, Life and the Soul. Leiden: Brill.

---. 2019. “Telesio, Aristotle and Hippocrates on Cosmic Heat." In Bernardino Telesio and the Natural Sciences in the Renaissance, ed. Pietro Daniel Omodeo, 51-65. Leiden: Brill.

Ingegno, Alfonso. 1980. Saggio sulla filosofia di Cardano. Florence: Nuova Italia.

Kessler, Eckhard. 1988. “The Intellective Soul.” In The Cambridge History of Renaissance Philosophy, ed. Charles B. Schmitt and Quentin Skinner, 485-534. Cambridge: Cambridge University Press. 
Kors, Alan Charles. 1990. Atheism in France, 1650-1729. Volume I: The Orthodox Sources of Disbelief. Princeton: Princeton University Press.

Maclean, Ian. 2003. "Cardano on the Immortality of the Soul." In Cardano e la tradizione dei saperi, ed. Marialuisa Baldiand Guido Canziani, 191-207. Milan: Angeli.

---. 2008. "Cardano’s Eclectic Psychology and Its Critique by Julius Caesar Scaliger.” Vivarium, 46:392-417.

Michael, Emily. 2000. "Renaissance Theories of Body, Soul, and Mind.” In Psyche and Soma: Physicians and Metaphysicians on the Mind-Body Problem from Antiquity to the Enlightenment, ed. John P. Wright and Paul Potter, 148-72. Oxford: Clarendon Press.

Moreau, Elisabeth. 2015. "Innate Heat.” In Encyclopedia of Renaissance Philosophy, ed. Marco Sgarbi. Dordrecht: Springer.

North, John D. 1980. “Astrology and the Fortunes of Churches.” Centaurus, 24:181-211.

Park, Katharine. 1988. “The Organic Soul.” In The Cambridge History of Renaissance Philosophy, ed. Charles B. Schmitt and Quentin Skinner, 464-484. Cambridge: Cambridge University Press.

Regier, Jonathan. 2014. "Kepler's Theory of Force and His Medical Sources." Early Science and Medicine 19: 1-27.

---. 2019. "Reading Cardano with the Roman Inquisition: Astrology, Celestial Physics, and the Force of Heresy." Isis 110.

Sakamoto, Kuni. 2016. Julius Caesar Scaliger, Renaissance Reformer of Aristotelianism: A Study of his Exotericae Exercitationes. Leiden: Brill.

Schütze, Ingo. 2000. Die Naturalphilosophie in Girolamo Cardanos De subtilitate. Munich: Fink. 
Siraisi, Nancy G. 1997. The Clock and the Mirror: Girolamo Cardano and Renaissance Medicine. Princeton: Princeton University Press.

Valente, Michaela. 2003. “CCorrezioni d'autore' e censure dell'opera di Cardano.” In

Cardano e la tradizione dei saperi, ed. Marialuisa Baldi and Guido Canziani, 437-456.

Milan: Angeli.

---. 2017. "Facing the Roman Inquisition: Cardano and Della Porta.” Bruniana \& Campanelliana 23:533-540. 